\title{
Level of Participation of Women and Men Members in Dairy Husbandry
}

\author{
Tankit Kumar $^{1 *}$, Subodh Kumar ${ }^{2}$ and Krishna Kant ${ }^{2}$ \\ ${ }^{1}$ Department of Extension \& Communication Management, College of Home Science, ${ }^{2}$ ILFC, \\ College of Veterinary Science and Animal Husbandry, PhD Scholar Department of \\ Agricultural economics in NDUAT Kumarganj Ayodhya, India \\ *Corresponding author
}

\section{A B S T R A C T}

\section{Keywords}

Participation, Entrepreneurship, Milk cooperative societies, Dairy husbandry, Gender, women, Men

Article Info

Accepted:

22 January 2021

Available Online:

10 February 2021
India is a developing country. Agriculture and livestock husbandry plays crucial role in Indian rural economy. Dairy husbandry is an integral part of rural livelihood adopted as income generating activity by majority of the rural people. Women play a significant role in dairy development, even after many custom discriminations against them. Entrepreneurial attributes of one's personality indicate the success of an enterprise managed by individual. With this background an attempt have been made to study level of participation of women and men members in dairy husbandry practices, Milkipur block of Faizabad District in Uttar Pradesh, India. For the purpose multistage sample and single random sampling designs were applied and 100 dairy cooperative members (50 men and 50 women) were interviewed with the help of structured and pre-tested interview schedule. Ten entrepreneurial attributes were studied and its relationship with income generated through dairy husbandry was also confuted. The Overall Participation in dairy farming activities, the majority of male milk cooperative members in medium category (52\%). Likewise, in case of female milk cooperative members majority in medium category (76\%). Thus, it may be concluded that the female milk cooperative members were found better as compared to male milk cooperative members in Overall Participation in dairy farming activities Focused that out of twenty-one selected independent variables, only five variables i.e. extension contact, entrepreneurial behavior, milk production, milk consumption and milk marketed were found highly significantly $(\mathrm{P} \leq 0.01)$ and positively correlated with the income through dairy cooperative. That is out of twenty-one selected independent variables, only four variables i.e. Social Participation, Participation in Health care, milk production and milk consumption were found significantly $(\mathrm{P} \leq 0.05)$ and positively correlated with the employment through dairy cooperative. The both dependent variables income generation and employment generation are positively and significantly $(\mathrm{P} \leq 0.05)$ correlated with each other.

\section{Introduction}

India is a vast country with diversified agroclimatic conditions. Agriculture is the main occupation in the country, majority of population still dependent on agriculture and allied sector. Most of the farmers are engaged in agricultural operations for about 8-9 
months of a calendar year. Dairy husbandry being an integral part of rural livelihood adopted as income generation activity by majority of rural poor. In present scenario small land holding is a major problem in agriculture sector so dairy husbandry may be an important substitutional occupation provides regular employment and income to the rural farmers. Involvement of Indian women in national progress at all levels is undisputable reality although the degree of involvement varies from time to time and region to region. The prosperity and growth of a nation depends on the status and development of its women as they not only constitute nearly half of the population, but also positively influence the growth of remaining half of the population. The crucial role of women in agriculture, allied occupations and household activities has however been grossly underestimated and undervalued. Women play significant and crucial role in agricultural development and allied fields like dairy farming, mushroom production, pisciculture etc. Dairy farming is major occupation of rural women. Cooperative society play significant role in dairy development in India.

The dairy co-operatives are the effective instrument to earn more profit while providing market infrastructure for timely sale of milk at reasonable price. The average income of the members through the supply of milk to cooperative society per annum increased considerably over a decade. The dairy co- operatives provide the opportunity of incentives and encouragement especially to the poor farmers for augmenting milk production and earning more profits through the supply of milk owing to remunerative prices. These pave the way for the up gradation of their socio- economic level and the resultant higher standard of living (Tiwari, 2001).

\section{Materials and Methods}

Uttar Pradesh is a leading state in milk production in the country. Co-operative societies plays important role in entrepreneurship development especially in dairy sector. In Faizabad district milk cooperative societies are functional and playing crucial role in motivating the farmers to adopt dairy enterprise, thus, Faizabad district was selected purposively. District Faizabad comprised of 11 blocks namely Sohawal, Masodha, Purabazar, Mayabazar, Milkipur, Amaniganj, Bikapur, Tarun, Haringtanganj, Rudauli and Mawai. Out of these 11 blocks the Milkipur block was selected purposively.

In milkipur block 28 milk cooperatives societies were function under cooperative milk union Faizabad at the time of investigation. Out of these, 10 milk cooperative societies were selected randomly. Applying simple random sampling design. Five women and five men members were selected for each of the selected milk cooperative society. Thus a total of 100 members (50 men and 50 women) were finally identified for the purpose of investigation. A structured and pretested interview schedule was applied for data collection. The data was collected through personal interview of the respondent, observation and secondary sources.

The appropriate statistical tools and techniques were used to analyze the data and draw inferences accordingly. The participation of men and women cooperative members was recorded in various aspects of dairy farming like feeding management, breeding management, the health care management, processing \& marketing management as well as general management each aspect was comprised with various activities related to it and response were recorded in three continuum scale as never, 
same time and always participation in the particular activity then scores were assigned as 0,1 , and 2 respectively. On the basis of scores the respondents were categorized into low (mean-SD), medium (mean $\pm \mathrm{SD}$ ), and high (mean $+\mathrm{SD})$ respectively.

The coefficient of simple correlation ( $r$ ) in a measure of the mutual relationship between two variables that in i.e. $x$ and $y$, where relationship is measured and commonly termed as product movement correlation coefficient and is computed by the following formula:

$$
\mathrm{r}=\frac{\sum(\mathrm{xi}-\overline{\mathrm{X}})(\mathrm{yi}-\overline{\mathrm{Y}})}{\sum(\mathrm{xi}-\overline{\mathrm{X}})(\mathrm{yi}-\overline{\mathrm{Y}})}
$$

\section{Results and Discussion}

\section{Participation in feeding management activities}

The data from the table 1 reveals the predominance of female cooperative members in feeding management of dairy animals as majority of them $(68 \%)$ were in high category followed by medium (24\%)and few (8\%) in low categories.

Contrast to it majority of the male respondents $(42 \%)$ were found belonging to low category followed by medium (32\%) and (26\%) category respectively. In pooled sample majority of the members $(47 \%)$ were belonged to high while 28 percent in medium and one forth of them were in low category of participation in feeding management of dairy animals.

\section{Participation in breeding management activities}

Table 2 revealed that half of the male respondents were found in high category of their participation in breeding related activities whereas 40 percent in medium and 10 percent in low category. Moreover majority of the female cooperative members $(80 \%)$ were in medium category and 20 percent live in low category. Surprisingly no female respondent was fell in high category.

Pooled figure indicate that majority $(16 \%)$ of cooperative members belonged to medium, 15 percent in low and one fourth of them live in high category. Result indicates that these were predominance of male members for participation in breeding most activities of dairy animals.

\section{Participation in health care management activities}

Table 3 shows that majority of the male cooperative members (56\%) had medium level of participation in health related activities followed by 24 percent in high and 20 percent in low category. Likewise majority of the female members irrespective of gender members $(52 \%)$ were in medium category and 48 percent fell in high category.

It is interesting that no female member was found in low category irrespective of gender majority of the respondents (54\%) were in medium category followed by high $(36 \%)$ and low $(10 \%)$ category, respectively.

\section{Participation in processing and marketing management activities}

The data given in Table 4 reveals that the majority of male milk cooperative members in medium category (52\%) followed by high (34\%) and low (14\%) category respectively.

Likewise, in case of female milk cooperative members majority of them were found in medium category where 20 percent in low and the rest 18 percent in high category. 
Table.1 Distribution of respondents according to their participation in feeding management activities

\begin{tabular}{|l|l|c|c|c|}
\hline S. No. & \multicolumn{1}{|c|}{ Categories (Scores) } & \multicolumn{3}{|c|}{ Respondents } \\
\cline { 3 - 5 } & & $\begin{array}{c}\text { Male } \\
\mathbf{n = 5 0}\end{array}$ & $\begin{array}{c}\text { Female } \\
\mathbf{n = 5 0}\end{array}$ & $\begin{array}{c}\text { Total } \\
\mathbf{N = 1 0 0}\end{array}$ \\
\hline 1. & Low (up to 7.88) & $21(42)$ & $4(8)$ & $\mathbf{2 5}(\mathbf{2 5})$ \\
\hline 2. & Medium (7.89 to 10.21) & $16(32)$ & $12(24)$ & $\mathbf{2 8}(\mathbf{2 8})$ \\
\hline $\mathbf{3 .}$ & High (10.22 and) & $\mathbf{1 3 ( 2 6 )}$ & $\mathbf{3 4}(\mathbf{6 8})$ & $\mathbf{4 7}(\mathbf{4 7})$ \\
\hline
\end{tabular}

Figures in parentheses indicate percentages. Mean $=9.05, \quad$ S.D. $=1.17, \quad$ Min=6, $\quad \operatorname{Max}=10$

Table.2 Distribution of respondents according to their participation in breeding management activities

\begin{tabular}{|l|l|c|c|c|}
\hline \multirow{2}{*}{$\begin{array}{c}\text { S. } \\
\text { No. }\end{array}$} & \multicolumn{1}{|c|}{ Categories (Scores) } & \multicolumn{3}{|c|}{ Respondents } \\
\cline { 3 - 5 } & & $\begin{array}{c}\text { Male } \\
\mathbf{n = 5 0}\end{array}$ & $\begin{array}{c}\text { Female } \\
\mathbf{n = 5 0}\end{array}$ & $\begin{array}{r}\text { Total } \\
\text { N=100 }\end{array}$ \\
\hline 1. & Low (up to 5) & $5(10)$ & $10(20)$ & $\mathbf{1 5}(\mathbf{1 5})$ \\
\hline 2. & Medium (6 to 8) & $20(40)$ & $40(80)$ & $\mathbf{6 0}(\mathbf{6 0})$ \\
\hline 3. & High $(\mathbf{9}$ and above) & $\mathbf{2 5 ( 5 0 )}$ & $\mathbf{0}(\mathbf{0})$ & $\mathbf{2 5}(\mathbf{2 5})$ \\
\hline
\end{tabular}

Figures in parentheses indicate percentages.

Mean $=7.04, \quad$ S.D. $=1.92, \quad \operatorname{Min}=2, \quad \operatorname{Max}=10$

Table.3 Distribution of respondents according to their participation in health care management activities

\begin{tabular}{|l|l|l|l|l|}
\hline $\begin{array}{c}\text { S. } \\
\text { No. }\end{array}$ & \multicolumn{1}{|c|}{ Categories (Scores) } & \multicolumn{3}{|c|}{ Respondents } \\
\cline { 3 - 5 } & & \multicolumn{1}{|c|}{$\begin{array}{c}\text { Male } \\
\text { n=50 }\end{array}$} & $\begin{array}{c}\text { Female } \\
\text { n=50 }\end{array}$ & $\begin{array}{r}\text { Total } \\
\mathbf{N = 1 0 0}\end{array}$ \\
\hline 1. & Low (up to 6) & $10(20)$ & $0(0)$ & $\mathbf{1 0}(\mathbf{1 0})$ \\
\hline 2. & Medium (7 to 9) & $28(56)$ & $26(52)$ & $\mathbf{5 4}(\mathbf{5 4})$ \\
\hline 3. & High (10 and above) & $\mathbf{1 2 ( 2 4 )}$ & $\mathbf{2 4}(\mathbf{4 8})$ & $\mathbf{3 6}(\mathbf{3 6})$ \\
\hline
\end{tabular}

Figures in parentheses indicate percentages.

Mean $=8.81, \quad$ S.D. $=1.96, \quad$ Min $=4, \quad M a x=18$

Table.4 Distribution of respondents according to their participation in processing and marketing management activities

\begin{tabular}{|c|l|c|c|c|}
\hline \multirow{2}{*}{$\begin{array}{c}\text { S. } \\
\text { No. }\end{array}$} & \multicolumn{1}{|c|}{ Categories (Scores) } & \multicolumn{3}{|c|}{ Respondents } \\
\cline { 3 - 5 } & & $\begin{array}{c}\text { Male } \\
\mathbf{n = 5 0}\end{array}$ & $\begin{array}{c}\text { Female } \\
\mathbf{n = 5 0}\end{array}$ & $\begin{array}{c}\text { Total } \\
\mathbf{N}=\mathbf{1 0 0}\end{array}$ \\
\hline 1. & Low (up to3 & $7(14)$ & $10(20)$ & $\mathbf{1 7}(\mathbf{1 7})$ \\
\hline 2. & Medium (4 to 5) & $26(52)$ & $31(62)$ & $\mathbf{5 7}(\mathbf{5 7})$ \\
\hline 3. & High (6 and above) & $\mathbf{1 7}(\mathbf{3 4})$ & $\mathbf{9}(\mathbf{1 8})$ & $\mathbf{2 6}(\mathbf{2 6})$ \\
\hline
\end{tabular}

Figures in parentheses indicate percentages.

Mean $=4.64, \quad$ S.D. $=1.04, \quad$ Min $=3, \quad$ Max $=6$ 
Table.5 Distribution of respondents according to their participation in general management activities

\begin{tabular}{|l|l|c|c|c|}
\hline \multirow{2}{*}{$\begin{array}{c}\text { S. } \\
\text { No. }\end{array}$} & \multicolumn{1}{|c|}{ Categories (Scores) } & \multicolumn{3}{|c|}{ Respondents } \\
\cline { 3 - 5 } & & $\begin{array}{c}\text { Male } \\
\text { n=50 }\end{array}$ & $\begin{array}{r}\text { Female } \\
\text { n=50 }\end{array}$ & $\begin{array}{c}\text { Total } \\
\text { N=100 }\end{array}$ \\
\hline 1. & Low (up to 7) & $17(34)$ & $2(4)$ & $\mathbf{1 9}(\mathbf{1 9})$ \\
\hline 2. & Medium (8 to 10) & $26(52)$ & $43(86)$ & $\mathbf{6 9}(\mathbf{6 9})$ \\
\hline 3. & High (11 and above) & $\mathbf{7 ( 1 4 )}$ & $\mathbf{5 ( 1 0 )}$ & $\mathbf{1 2}(\mathbf{1 2})$ \\
\hline
\end{tabular}

Figures in parentheses indicate percentages.

Mean $=8.85, \quad$ S.D. $=1.66, \quad$ Min $=5, \quad M a x=14$

Table.6 Distribution of respondents according to Overall Participation in dairy farm activities

\begin{tabular}{|l|l|c|c|c|}
\hline \multirow{2}{*}{$\begin{array}{c}\text { S. } \\
\text { No. }\end{array}$} & \multicolumn{1}{|c|}{ Categories (Scores) } & \multicolumn{3}{|c|}{ Respondents } \\
\cline { 3 - 5 } & & $\begin{array}{c}\text { Male } \\
\text { n=50 }\end{array}$ & $\begin{array}{c}\text { Female } \\
\text { n=50 }\end{array}$ & $\begin{array}{c}\text { Total } \\
\text { N=100 }\end{array}$ \\
\hline 1. & Low (up to 34) & $15(30)$ & $4(8)$ & $\mathbf{1 9}(\mathbf{1 9})$ \\
\hline 2. & Medium (35 to 42) & $26(52)$ & $38(76)$ & $\mathbf{6 4}(\mathbf{6 4})$ \\
\hline 3. & High (43 and above) & $\mathbf{9 ( 1 8 )}$ & $\mathbf{8}(\mathbf{1 6})$ & $\mathbf{1 7}(\mathbf{1 7})$ \\
\hline
\end{tabular}

Figures in parentheses indicate percentages.

Mean $=38.39, \quad$ S.D. $=4.69, \quad$ Min $=27, \quad \operatorname{Max}=50$

Table.7 Deference in the mean values of participation in dairy activities among male and female cooperative members

\begin{tabular}{|c|c|c|c|c|}
\hline \multirow[t]{2}{*}{ S. No. } & \multirow[t]{2}{*}{ Socio-economic Variable } & \multicolumn{2}{|c|}{ Mean values } & \multirow[t]{2}{*}{$t$ values } \\
\hline & & $\begin{array}{l}\text { Male } \\
\mathrm{N}=50\end{array}$ & $\begin{array}{c}\begin{array}{c}\text { Female } \\
N=50\end{array}\end{array}$ & \\
\hline 1. & Feeding management & 8.50 & 9.60 & $7.9100 * *$ \\
\hline 2. & Breeding management & 7.82 & 6.26 & $2.5400 * *$ \\
\hline 3. & Health care management & 8.22 & 9.40 & $0.0023^{\mathrm{NS}}$ \\
\hline 4. & Processing and marketing management & 4.78 & 4.50 & $0.1835^{\mathrm{NS}}$ \\
\hline 5. & General management & 8.60 & 9.10 & $0.1341^{\mathrm{NS}}$ \\
\hline 6. & Overall participation & 37.92 & 38.86 & $0.3196^{\mathrm{NS}}$ \\
\hline
\end{tabular}

** Significant at $1 \%$ probability level NS- Non Significant

Pooled data indicate that majority of the respondents $(57 \%)$ were found belonging to medium category followed by high (26\%) and low $(17 \%)$ categories respectively.

Participation in general management activities

The data given in Table 5 shows that the majority of male milk cooperative members
$(52 \%)$ were in medium category (52\%) followed by low (34\%) and high (14\%) categories respectively.

Likewise, in case of female milk cooperative members majority of them $(86 \%)$ were in medium category, 10 percent in high while very few lie in low category of participation in general management practices. 
Irrespective of gender, 69 percent of the respondents shown medium while (19\%) low and 12 percent high level of participation in general management activities of dairy animals.

\section{Overall participation in dairy farm activities}

The data given in Table 6 reveals that the majority of male milk cooperative members $(52 \%)$ were found in medium category followed by low (30\%) and high (18\%) categories, respectively. Likewise, in case of female milk cooperative members majority of them $(76 \%)$ were in medium category $(76 \%)$ followed by high (16\%) and low (8\%) categories respectively.

Pooled sample indicate that majority of the dairy farmers $(64 \%)$ were having medium level of participation in dairy farm activity whereas almost equal number of respondent shown low and high of participation.

\section{Difference in mean value of participation in dairy farming activity among male and female cooperative members}

It is evident from the table 7 that male members were significantly $(\mathrm{P}<0.01)$ might as compared to female member in terms of participation in livestock breeding management activities. In contrast to at female cooperative members were significantly $(\mathrm{P}<0.01)$ higher than the male members in term of feeding management of dairy animals. It might be because of most of feeding management activities are indoor activities which are commonly performed by female in the family while outdoor activities like in breeding management are commonly undertaken by the male family members.

Furthermore, no significant difference between males \& females was observed in term of heath care management as well as processing \& marketing management. Thus no significant difference between both the genders was observed in their participation in dairy management activities. It indicate that females are equally participant in dairy management activities as male family members in rural areas.

In conclusion the extent of participation in dairy farming activities was found vary in different activities was amongst male and female cooperative members. They need to provide adequate technical support by way of imparting training on regular basis. The female cooperative member mostly engaged in Indore activities and of dairy husbandry and male cooperative members mostly involved in outdoor activities.

\section{References}

Amul - The Taste of India. "Welcome to Amul - The Taste of India". Amul.com. Retrieved 12 July 2010.

Batool, Z., Warriach, H. M., Ishaq, M., Latif, S., Afzal, M., Bhatti, A., Murtaza, N., Arif, S. and Wynn, P. C. (2012). Participation of Women in Dairy Farm Practices under Small Holder Production System in Pakistan. Proceedings of the 15th AAAP Animal Science Congress.

Jadhav, S. G., Ahire, M. C. and Sonawane, H. P. (2011). Role performance of women members in dairy co-operative societies. Mysore journal of Agricuture science. 45(4): 949-951.

Nandapurkar, G. G. (1982). Small Farmers, a Study on Their Entrepreneurial Behaviour Metropolitan Book co. PVT LTD.

Rathod, P.K., Nikam, T. R., Landge, S., Vajreshwari, S. and Hatey, A. (2011). Participation of rural women in dairy farming in Karnataka. Indian Research 
Journal of Extension Education. 11(2):31-36.

Saxena D. (1996). Entrepreneurship behavior of milk producer in women and men cooperative societies M.Sc. thesis IVRI
Izatnaga Bareilly. Tiwari, M.K, (2001) "Profitable Milk Business through Dairy Co-operative", Agricultural Extension Review, 13(3): 20-22.

\section{How to cite this article:}

Tankit Kumar, Subodh Kumar and Krishna Kant. 2021. Level of Participation of Women and Men Members in Dairy Husbandry. Int.J.Curr.Microbiol.App.Sci. 10(02): 3078-3084. doi: https://doi.org/10.20546/ijcmas.2021.1002.336 